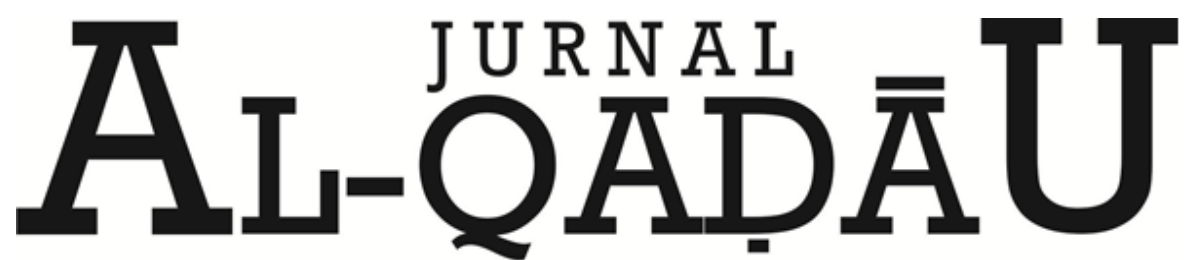 \\ PERADILAN dan HUKUM KELUARGA ISLAM
}

\section{Penyelesaian Sengketa Hak atas Tanah Bersertifikat dan Tidak Bersertifikat}

\section{Settlement of Land Rights Disputes for Certified and Not Certified}

Basyirah Mustarin

Dosen Fakultas Syariah dan Hukum UIN Alauddin Makassar

Email : basyirahbabas@gmail.com.

\begin{tabular}{|c|c|}
\hline Info & Abstract \\
\hline $\begin{array}{l}\text { Diterima } \\
29 \\
\text { September } \\
2017\end{array}$ & $\begin{array}{l}\text { Keberadaan sertifikat hak atas tanah merupakan hasil dari proses } \\
\text { pendaftaran tanah. Sebagaimana disebutkan dalam Pasal } 19 \text { ayat (2) } \\
\text { UUPA bahwa pendaftaran tanah meliputi beberapa rangkaian kegiatan } \\
\text { yang diakhiri dengan pemberian surat-surat tanda bukti hak yang berlaku } \\
\text { sebagai alat pembuktian yang sah. Alat pembuktian yang sah bagi } \\
\text { kepemilikan hak atas tanah adalah dalam bentuk sertifikat hak atas tanah. } \\
\text { Sertifikat adalah salinan buku tanah dan surat ukur (untuk pendaftaran } \\
\text { tanah sistemik) atau gambar situasi (untuk pendaftaran tanah sporadik) } \\
\text { yang dijahit menjadi satu dan bentuknya ditetapkan oleh Menteri. Dengan } \\
\text { demikian maka dapat dikatakan apabila suatu hak atas tanah tersebut } \\
\text { mempunyai sertifikat sebagai tanda bukti haknya. Sebaliknya apabila } \\
\text { suatu hak atas tanah belum mempunyai sertifikat berarti tanah tersebut } \\
\text { didaftarkan sebagaimana yang diwajibkan oleh peraturan perundang- } \\
\text { undangan yang berlaku. Keberadaan sertifikat hak atas tanah mempunyai } \\
\text { arti penting yang menandakan bahwa hak atas tanah bersangkutan telah } \\
\text { didaftarkan dimana hal itu dibuktikan dengan adanya (diterbitkannya) } \\
\text { sertifikat oleh instansi yang berwenang. }\end{array}$ \\
\hline
\end{tabular}

24

Nopember

2017

\section{Disetujui}

20

Desember

2017
Kata Kunci : Sertifikat, Tanah.

The existence of the land title certificate is the result of the land registration process. As mentioned in Article 19 Paragraph (2) UUPA, that land registration covers several series of activities ending with the provision of proof of papers valid as valid evidence. The legal proof of ownership of land rights is in the form of land title certificates. The certificate is a copy of a land and measuring book (for systemic land registration) or a situation picture (for sporadic land registration) stitched together and the form designated by the Minister.Thus it can be said if a right to the land has a certificate as a proof of its right. Conversely, if a right to land does not have a certificate, the land is registered as required by the applicable laws and regulations. The existence of a land title certificate has significance indicating that the right to the land has been registered where it is proved by the issuance of certificate by the authorized institution.

Keywords: Certificate, land. 
Basyirah Mustarin

\section{PENDAHULUAN}

Tanah adalah kebutuhan, setiap manusia selalu berusaha untuk memilikinya, dan tetap mempertahankannya apapun yang terjadi. Tanah dapat dimiliki siapa saja, individu, masyarakat sebagai kelompok, atau badan hukum. Suatu ketika tanah menjadi warisan atau aset perusahaan bahkan menjadi benda keramat untuk diperebutkan sebab memiliki nilai ekonomis yang akan naik nilainya setiap tahunnya dan hal tersebutlah yang menimbulkan konflik tanah.

Tanah mempunyai peranan yang besar dalam dinamika pembangunan, maka didalam Undang-Undang Dasar 1945 pasal 33 ayat 3 disebutkan bahwa Bumi dan air dan kekayaan alam yang terkandung didalamnya dikuasai oleh negara dan dipergunakan untuk sebesar-besar kemakmuran rakyat. Ketentuan mengenai tanah juga dapat kita lihat dalam Undang-Undang Republik Indonesia Nomor 5 Tahun 1960 tentang Peraturan Dasar Pokok-Pokok Agraria atau yang biasa kita sebut dengan UUPA. ${ }^{1}$ Timbulnya sengketa hukum yang bermula dari pengaduan sesuatu pihak (orang/badan) yang berisi keberatan-keberatan dan tuntutan hak atas tanah, baik terhadap status tanah, prioritas, maupun kepemilikannya dengan harapan dapat memperoleh penyelesaian secara administrasi sesuai dengan ketentuan yang berlaku. Mencuatnya kasus-kasus sengketa tanah di Indonesia beberapa waktu terakhir seakan kembali menegaskan kenyataan bahwa selama 62 tahun Indonesia merdeka, negara masih belum bisa memberikan jaminan hak atas tanah kepada rakyatnya. Undang-Undang Nomor 5 Tahun 1960 tentang Undang-Undang Pokok Agraria (UUPA) baru sebatas menandai dimulainya era baru kepemilikan tanah yang awalnya bersifat komunal berkembang menjadi kepemilikan individual.

Kasus-kasus yang menyangkut sengketa di bidang pertanahan dapat dikatakan tidak pernah surut, bahkan mempunyai kecenderungan untuk terus meningkat didalam kompleksitasnya maupun kuantitasnya seiring dinamika dibidang ekonomi, sosial, dan politik. Bergulirnya reformasi yang dimulai pertengahan tahun 1998, akhirnya bergerak di segala bidang termasuk diantaranya bidang Pertanahan. Sejak dahulu persoalan pertanahan selalu ada dan menarik untuk dibahas penyelesaiannya. Reformasi

\footnotetext{
${ }^{1}$ Adrian Sutedi, Peralihan Hak Atas Tanah Dan Pendaftarannya (Jakarta: Sinar Grafika, 2007), h. 112.
} 
tampaknya menyadari sebagian masyarakat tentang penegakan tatanan Pemerintah yang mendasarkan pada Undang- Undang Dasar 1945. Sengketa tanah dalam masyarakat seringkali terjadi dalam hal ini semakin tahun semakin meningkat dan terjadi hampir di seluruh daerah di Indonesia baik di daerah perkotaan maupun di pedesaan. Persoalan tanah selama ini sangat relevan untuk dikaji bersama-sama dan dipertimbangkan secara mendalam dan seksama dalam kaitannya dengan kebijakan dibidang pertanahan selama ini. Hal ini disebabkan oleh karena ditingkat implementasi kebijakan yang diperlihatkan selama ini telah mengabaikan aspek struktural penguasaan tanah yang pada akhirnya menimbulkan berbagai macam sengketa.

Dalam melakukan tindakan penyelesaian sengketa atau konflik pertanahan yang ada, badan pertanahan nasional merupakan salah satu lembaga mediasi yang dapat menyelesaikan suatu sengketa pertanahan dengan mengedepankan keadilan, yaitu penyelesaian konflik melalui musyawarah mufakat dengan menghormati hak dan kepentingan para pihak yang bersengketa yang prinsip dasarnya adalah solusi samasama menang atau dikenal dengan istilah "win-win solution" atau normatifnya disebut jalan penyelesaian "Non-Litigation" atau Alternative Despute Resulution (ADR), yang selanjutnya untuk mewadahi pelaksanaan ADR tersebut Pemerintah melalui Undangundang Nomor 30 Tahun 1999 tentang Arbitrase dan Alternatif Penyelesaian Sengketa. Aturan inilah yang menjadi tolok ukur untuk mengetahui seberapa pentingnya lembaga mediasi didalam penyelesaian konflik tanah. ${ }^{2}$

\section{PEMBAHASAN}

\section{Eksistensi Pemilikan Hak Atas Tanah Berdasarkan Hukum Pertanah}

Setelah Indonesia merdeka, penguasaan tanah secara umum dikuasai oleh Negara sebagaimana diatur dalam pasal 33 ayat (3) UUD 1945 yang menyatakan bahwa "bumi dan air dan kekayaan alam yang terkandung di dalamnya dikuasai oleh Negara dan dipergunakan untuk sebesar-besarnya kemakmuran rakyat”. Hal ini bukan berarti rakyat tidak boleh memiliki hak atas tanah baik secara individu maupun kelompok,

${ }^{2}$ Takdir Rahmadi, Mediasi: Penyelesaian Sengketa Melalui Pendekatan Mufakat (Jakarta: PT Rajagrafindo Persada, 2010), h. 66. 
Basyirah Mustarin

namun demikian Negara yang bertanggungjawab atas pengelolaan dan pengaturan secara nasional atas tanah di Indonesia.

Dengan demikian setiap warga Negara, kelompok masyarakat atau badan hukum dapat memiliki hak atas tanah sesuai dengan jenis yang ditetapkan dalam ketentuan dimaksud. Selain dikenal jenis-jenis hak tanah juga ditetapkan bukti kepemilikan dan punguasahaan hak tanah secara sah, sebagaimana diatur dalam pasal 19 ayat (1) UU No.5 Tahun 1960 tentang UUPA yang substansinya menyatakan bahwa: "Untuk menjamin kepastian hukum oleh Pemerintah diadakan pendaftaran tanah di seluruh wilayah Republik Indonesia menurut ketentuan-ketentuan yang diatur dengan Peraturan Pemerintah". Pendaftaran tanah dilakukan untuk menjamin kepastian hukum bagi masyarakat dalam memiliki, menguasai dan memanfaatkan tanah, karena itu bagi penguasaan tanah yang telah didaftarkan akan diterbitkan surat tanda bukti hak berupa "sertifikat".

Mengenai pengertian sertifikat hak atas tanah diatur dalam pasal 13 Peraturan Pemerintah No.10 Tahun 1961 tentang Pendaftaran Tanah, khususnya dalam ayat (3) dirumuskan, bahwa: "Salinan buku tanah dan surat ukur setelah dijahit menjadi satu bersama-sama dengan suatu kertas sampul yang bentuknya ditetapkan oleh Menteri Agraria, disebut sertifikat dan diberikan kepada yang berhak”. Selanjutnya dalam ayat (4) dikatakan: "Sertifikat tersebut pada ayat (3) pasal ini adalah surat tanda bukti hak yang dimaksud dalam pasal 19 UUPA”. Ketentuan undang-undang dimaksud mengikat, sehingga setiap warga Negara (rakyat) atau masyarakat sebagai pemilik hak atas tanah diwajibkan untuk mendaftarkan tanah yang dikuasainya dan akan diberikan salinan buku tanah yang disebut "sertifikat", yang merupakan surat tanda bukti hak. Dengan demikian "sertifikat" sebagai salinan buku tanah yang memiliki ketentuan hukum tertinggi.

Oleh karena itu seseorang atau kelompok masyarakat atau badan hukum yang telah menguasai tanah dan memiliki tanda bukti sertifikat tanah dapat mengklaim dirinya sebagai pemilik yang sah, namun demikian tidak menutup kemungkinan dan bukti-bukti lain di luar sertifikat yang dapat dilakukan secara serentak yang dipengaruhi kondisi masyarakat, kesiapan aparat dan pembiayaan, maka alat-alat bukti lain tersebut tetap dapat dijadikan petunjuk mengenai adanya hak atas tanah milik seseorang atau badan hukum. Di sini lahir stelsel negatif, yang artinya terbuka kemungkinan untuk 
menggugurkan hak seseorang/ pihak sekiranya ada pihak/ orang lain yang lebih berhak atasnya.

Asas stelsel negatif yang dianut hukum agraria nasional adalah bertujuan untuk “memberikan perlindungan terhadap pemilik yang berhak". Hal ini sangat berbeda dengan asas positif yang memberikan perlindungan pada pemilik yang terdaftar atau tercantum dalam buku tanah. Jadi bukannya sertifikat yang menentukan hak suatu pihak atau seseorang atas tanah, sehingga kekuatan sertifikat ditopang dengan adanya hubungan hukum dimaksud. Artinya dengan stelsel positif maka yang namanya tercantum dalam sertifikat tanah adalah dianggap sebagai orang yang benar-benar berhak atas tanah terebut. Sedang apabila ada hak orang lain di atasnya, maka pemegang hak atas tanah namanya tercantum dalam sertifikat wajib memberikan ganti rugi kepada yang orang berhak jika terjadi pelanggaran dalam penguasaan hak atas tanah tersebut, tanpa menggugurkan hak orang yang namanya telah tercantum pada sertifikat tanah tersebut.

Dengan demikian dapat dipahami, bahwa masih ada dua konsep kepemilikan atau penguasaan hak tanah, yakni penguasaan tanah yang telah terdaftar atau "bersertifikat" yang mendapatkan pengakuan utama, dan penguasaan tanah yang belum terdaftar atau yang "belum bersertifikat" yang juga mendapatkan pengakuan walaupun lebih rendah derajat pengakuannya.

Menurut pasal 3 Peraturan Pemerintahan No. 24 Tahun 1997 Tentang Pendaftaran Tanah yang merupakan pengganti dari Peraturan Pemerintah Nomor 10 Tahun 1961 dikatakan bahwa pendaftaran tanah dilakukan memiliki tujuan, antara lain:

1. Untuk memberikan kepastian hukum dan perlindungan hukum kepada pemegang hak atas suatu bidang tanah, satuan rumah susun dan hak-hak lain yang terdaftar agar dengan mudah dapat membuktikan dirinya sebagai pemegang hak yang bersangkutan,

2. Untuk menyediakan informasi kepada pihak-pihak yang berkepentingan termasuk Pemerintah agar dapat dengan mudah memperoleh data yang diperlukan dalam mengadakan perbuatan hukum mengenai bidang-bidang tanah dan satuan-satuan rumah susun yang sudah terdaftar,

3. Untuk terselenggaranya tertib administrasi pertanahan. 
Basyirah Mustarin

Apabila dicermati secara mendalam dari ide dasar dan tujuan utama (main purpose) penyelenggaraan pendaftaran hak tanah sebagaimana tersebut di atas maka dapat dipahami bahwa pemilik tanah yang telah didaftarkan lebih memiliki kepastian hukum dan terjamin perlindungannya secara hukum dibandingkan dengan yang belum didaftarkan (belum bersertifikat). Namun demikian bukan berarti tidak mengakui bagi pemilik tanah yang belum didaftarkan. Apabila terdapat hak orang lain maka orang yang berhak tersebut dapat mengajukan gugatan ke pengadilan. Jika terbukti bahwa pihak yang tercantum dalam sertifikat ternyata tidak berhak, maka pengadilan dapat membatalkan sertifikat tersebut dan memerintahkan penggantian nama orang yang berhak atas tanah dalam sertifikat dimaksud. ${ }^{3}$

\section{Jenis-Jenis Hak Atas Tanah}

Pada tahun 1960 dengan dibentuknya Undang Undang Hukum Agraria Nasional, yakni Undang-Undang No.5 Tahun 1960 tentang Pokok-pokok Peraturan Dasar Agraria, yang dikenal juga sebagai Undang-Undang Pokok Agraria (UUPA) dan Peraturan Pemerintah No.20 Tahun 1961 tentang Pendaftaran Tanah (L.N. 1961 No.28) maka keberadaan hak eigendom yang diterapkan di Indonesia selama masa penjajahan Belanda dihapuskan, meskipun hukum agrarian nasional yang dibentuk tersebut juga masih bersifat pluralistik, karena yang dijadikan landasan adalah hukum adat yang bersifat pluralistis. Di dalam Undang-Undang No.5 Tahun 1960 tentang UUPA mengenai hak-hak atas tanah dirumuskan dalam Pasal 16 dimana dikenal adanya jenisjenis hak atas tanah, antara lain :

1. Hak Milik

Untuk sekarang ini, Hak Milik adalah yang terkuat dan terpenuh, dan berlaku turun-temurun dalam jangka waktu yang tidak terbatas, pemiliknya warga Negara Indonesia dan dimungkinkan badan hukum tertentu sesuai PP No. 38 Tahun 1963, dapat dialihkan kepada pihak lain, dapat dijadikan jaminan hutang, dapat hilang karena tanahnya jatuh kepada Negara yang disebabkan oleh pencabutan hak; penyerahan sukarela; ditelantarkan; pengalihan kepada warga Negara/badan hukum asing.

\footnotetext{
${ }^{3}$ Hartanto Andy J, hukum pertanahan karakteristik jual beli tanah yang belum terdaftar hak atas tanahnya (Surabaya : Laksbang justitia Surabaya, 2014), h. 16.
} 
2. Hak Guna Usaha

Biasanya Hak guna usaha ini diberikan untuk mengusahakan tanah yang dikuasai langsung oleh Negara dalam bidang usaha pertanian, perikanan atau peternakan, dan dengan jangka waktu yang terbatas dan dapat diperpanjang (maksimal 35 tahun). Pemiliknya warga Negara Indonesia dan atau badan hukum yang ada dan didirikan berdasarkan hukum Indonesia, dapat dialihkan kepada pihak lain serta dapat dijadikan jaminan hutang. Hak guna usaha ini dapat dihapus karena jangka waktunya berakhir; dihentikan jangka waktunya; dilepaskan oleh pemegangnya; dicabut untuk kepentingan umum; ditelantarkan; tanahnya musnah.

\section{Hak Guna Bangunan}

Hak guna bangunan ini berarti mendirikan dan mempunyai bangunan atas tanah yang bukan miliknya sendiri; dengan jangka waktu yang terbatas dan dapat diperpanjang (maksimal 30 tahun). Pemiliknya warga Negara Indonesia dan atau badan hukum yang ada dan didirikan berdasarkan hukum Indonesia yang dapat memiliki hak tersebut; dapat dialihkan kepada pihak lain; dapat dijadikan jaminan hutang. Hak guna bangunan ini akan tidak berlaku lagi karena jangka waktunya berakhir; dihentikan jangka waktunya; dilepaskan oleh pemegangnya; dicabut untuk kepentingan umum; ditelantarkan; tanahnya musnah.

\section{Hak Pakai}

Hak Pakai ini dapat dimiliki oleh warga negara Indonesia dan warga Negara asing yang berkedudukan di Indonesia dan atau badan hukum yang ada dan didirikan berdasarkan hukum Indonesia serta badan hukum asing yang mempunyai perwakilan di Indonesia yang dapat memiliki hak tersebut untuk menggunakan dan atau memungut hasil dari tanah yang dikuasai langsung oleh Negara atau tanah milik orang lain dalam jangka waktu tertentu selama tanahnya masih diperlukan (maksimal 25 tahun). Hak pakai ini dapat dialihkan kepada pihak lain ataupun jaminan hutang.

\section{Pembuktian Kepemilikan Atas tanah}

Dalam penjelasan Pasal 24 ayat (1) tersebut dikemukakan bahwa pemilikan itu pada dasarnya terdiri atas bukti pemilikan atas nama pemegang hak pada waktu berlakunya UUPA pada tanggal 24 September 1960 dan apabila hak tersebut kemudian 
Basyirah Mustarin

beralih, bukti peralihan hak berturut-turut sampai ke tangan pemegang hak pada waktu dilakukan pembukuan hak yang bersangkutan.

Dalam hal yang demikian, pembukuan haknya dilakukan melalui penegasan konversi hak yang lama menjadi hak baru yang didaftar. Selanjutnya dijelaskan dalam Penjelasan ayat (1), bahwa alat-alat bukti tertulis yang dimaksud dalam Pasal 24 ayat (1) di atas dapat berupa :

a. Grosse akta hak eigendom yang diterbitlkan berdasarkan Overschrijvings Ordonnantie (Staatsblad 1834-27) yang telah dibubuhi catatan, bahwa hak eigendom yang bersangkutan dikonversi menjadi Hak Milik atau;

b. Grosse akta hak eigendom yang diterbitkan berdasarkan Ordonnantie tersebut sejak berlakunya UUPA sampai tanggal pendaftaran tanah dilaksanakan menurut Peraturan Pemerinta No.10 Tahun 1961 di daerah yang bersangkutan atau;

c. Surat tanda bukti hak Milik yang diterbitkan berdasarkan Peraturan Swapraja yang bersangkutan atau;

d. Sertifikat Hak Milik yang diterbitkan berdasarkan Peraturan Menteri Agraria No. 9 Tahun 1959 atau;

e. Surat keputusan pemberian hak milik dari pejabat yang berwenang, baik sebelum atau sejak berlakunya UUPA, yang tidak disertai kewajiban untuk mendaftarkan hak yang diberikan, tetapi telah dipenuhi semua kewajiban yang disebut di dalamnya atau;

f. Akta pemindahan hak yang dibuat di bawah tangan, yang dibubuhi tanda kesaksian oleh Kepala Adat/ Kepala Desa/ Kelurahan, yang dibuat sebelum Peraturan Pemerintah No.10 Tahun 1961, yang menentukan bahwa harus ada bukti akta PPAT, sejak Peraturan Pemerintahan tersebut mulai dilaksanakan di suatu daerah atau;

g. Akta pemindahan hak atas tanah yang dibuat oleh PPAT, yang tanahnya belum dibukukan (seharusnya ditambahkan: atau tanahnya yang sudah dibukukan, tetapi belum diikuti pendaftaran pemindahan haknya pada Kator Pertanahan) atau;

h. Akta ikrar wakaf/ surat ikrar wakaf yang dibuat sebelumnya atau sejak mulai dilaksanakannya Peraturan Pemerintah No. 20 Tahun 1977 atau; 
i. Risalah lelang yang dibuat oleh Pejabat Lelang yang berwenang, yang tanahnya belum dibukukan (seharusnya ditambahkan: atau tanahnya yang sudah dibukukan, tetapi belum diikuti pendaftaran pemindahan haknya pada Kator Pertanahan) atau;

j. Surat penunjukan atau pembelian (seharusnya; pemberian kaveling tanah pengganti tanah yang diambik oleh Pemerintah atau Pemerintah Daerah atau;

k. Petuk Pajak Bumi/ Landrente, girik, pipil, kekitir, dan Verponding Indonesia sebelum berlakunya Peraturan Pemerintah No. 10 Tahun 1961 (seharusnya: sebelum berlakunya UUPA. Sejak mulai berlakunya UUPA tidak dipungut lagi Pajak Bumi, karena tidak ada lagi tanah Hak Milik Adat) atau;

1. Surat keterangan riwayat tanah yang pernah dibuat oleh Kantor Pelayanan Pajak Bumi dan Bangunan atau;

m. Lain-lain bentuk alat pembuktian tertulis dengan nama apapun juga sebagaimana dimaksud dalam Pasal II, Pasal VI dan Pasal VII ketentuan-ketentuan Konversi UUPA.

Dalam hak pemilihan bukti tertulis tersebut tidak lengkap, maka dapat dilakukan dengan keterangan saksi dan atau pernyataan pemilik tanah yang dapat dipercaya kebenaranya menurut pendapat Ajudikasi/ Kepala Kantor Pertanahan, demikian dijelaskan lebih lanjut dalam Penjelasan Ayat (1) Pasal 24 PP No.24 Tahun 1997 tentang Pendaftaran Tanah.

Keterangan saksi atau pernyataan yang bersangkutan mengenai pemilikan tanah itu berfungsi menguatkan bukti tertulis yang tidak lengkap tersebut, atau sebagai pengganti bukti tertulis yang tidak ada lagi. Yang dimaksud dengan saksi adalah orang yang cakap memberikan kesaksian dan mengetahui kepemilikan tanah yang bersangkutan.

Maka mengenai kepemilikan itu ada tiga kemumungkinan alat pembuktiannya, yaitu:

a. Bukti tertulisnya lengkap: tidak memerlukan tambahan alat bukti lain;

b. Bukti tertulisnya sebagian tidak ada lagi; diperkuat keterangan saksi dan atau pernyataan yang bersangkutan;

c. Bukti tertulisnya semuanya tidak ada lagi: diganti keterangan saksi dan atau pernyataan yang bersangkutan. 
Basyirah Mustarin

Akan tetapi, semua akan diteliti lagi melalui pengumuman untuk memberi kesempatan kepada pihak-pihak yang berkepentingan mengajukan keberatan.

Dalam Pasal 24 ayat (2) diatur pembukuan hak dalam hal tidak atau tidak lagi tersedia secara lengkap alat-alat pembuktian pemilikan yang tertulis, kebenarannya mengenai kepemilikan tanah yang bersangkutan, sebagaimana yang disebut dalam ayat (1) di atas. Dalam hal yang demikian, pembukuan haknya dapat dilakukan tidak didasarkan pada bukti pemilikan, melainkan pada bukti penguasaan fisik tanahnya oleh pemohon pendaftaran dan pendahuluan-pendahuluannya selama 20 tahun atau lebih secara berturut-turut.

Dalam penjelasan ayat (2) tersebut, dirinci syarat-syarat yang harus dipenuhi bagi pembukuan hak yang bersangkutan, yaitu:

a. Penguasaan dan penggunaan tanah yang bersangkutan dilakukan dengan itikad baik, secara nyata dan terbuka selama waktu yang disebut di atas;

b. Kenyataannya penguasaan dan penggunaan tanah tersebut selama itu tidak diganggu gugat karena itu dianggap diakui dan dibenarkan oleh masyarakat hukum adat atau desa/ kelurahan yang bersangkutan ataupun pihak lainnya;

c. Hal-hal tersebut, yaitu penguasaan dan penggunaan tanah yang bersangkutan srta tidak adanya gangguan, diperkuat oleh kesaksian orang-orang yang dapat dipercaya;

d. Telah diadakan penelitian mengenai kebenaran hal-hal yang disebutkan di atas;

e. Telah diberi kesempatan kepada pihak lain untuk mengajukan keberatan melalui pengumuman sebagaimana dimaksud Pasal 26;

f. Akhirnya kesimpulan mengenai status tanah dan pemegang haknya dituangkan dalam Keputusan berupa poengakuan hak yang bersangkutan oleh Panitia Ajudikasi/ Kepala Kantor Pertanahan.

Sertifikat sebagai surat tanda bukti hak, diterbitkan untuk kepentinagn pemegang hak yang bersangkutan sesuai dengan data fisik yang ada dalam surat ukur dan data yuridis yang telah didaftar dalam buku tanah. Memperoleh sertifikat adalah hak pemegang hak atas tanah, yang dijamin undang-undang.

Menurut Peraturan Pemerintah No. 10 Tahun 1961, sertifikat terdiri atas salinan buku tanah yang memuat data yuridis dan surat ukur yang memuat data fisik hak yang 
bersangkurtan, dijilid menjadi suatu dalam sampul dokumen (Pasal 13). Cara pembuatan sertifikat adalah seperti pembuatan buku tanah, dengan ketentuan bahwa catatan-catatan, yang bersifat sementara dan sudah dihapus tidak dicantumkan. Oleh karena itu, sertifikat merupakan alat pembuktian yang kuat, sebagaimana dinyatakan dalam pasal 19 UUPA. Sehubungan dengan itu apabila masih ada ketidakpastian mengenai hak atas tanah yang bersangkutan, yang tercatat dari masih adanya catatan dalam pembukuannya, pada prinsipnya sertifikat belum dapat diterbitkan. Namun apabila catatan itu belum lengkap, tetapi tidak disengketakan, sertifikat dapat diterbitkan.

\section{Praktek Penyelesaian Sengketa Tanah yang terjadi pada daerah pedesaan}

Konflik tanah kerap kali terjadi pada tanah yang belum didaftarkan kepemilkannya kepada Badan Pertanahan, hal tersebut akan sering kita jumpai pada tanah yang terletak di daerah-daerah pedesaan atau daerah pelosok yang masih kurang akan SDM yang mengetahui akan pentingnya pendaftaran tanah dilakukan. Adapun peran pemerintah desa dalam bentuk mendamaikan secara kekeluargaan, mengajukan mediasi (adanya pihak ketiga sebagai mediator dalam menjalankan tugasnya menengahi dan menyelesaikan sengketa antara para pihak yang harus berada pada posisi netral dan tidak memihak dalam menyelesaikan sengketa, Ia harus mampu menjaga kepentingan para pihak yang bersengketa secara adil dan sama, sehingga menumbuhkan kepercayaan (trust) dari para pihak yang bersengketa. Perdamaian adalah suatu persetujuan di mana kedua belah pihak dengan menyerahkan, menjanjikan atau menahan suatu barang, mengakhiri suatu sengketa yang sedang bergantung atau mencegah timbulnya suatu perkara, dan persetujuan perdamaian tidak sah melainkan harus dibuat secara tertulis dan bentuk penyelesaian sengketa yang dijalankan ini memiliki kelemahan, dimana tidak mengikat, bahkan kedua belah pihak yang telah setuju mengambil jalur damaipun kadang menggugat kembali karena merasa tidak adil, dan bentuk penyelesaian sengketa tanah ini pun tidak memiliki kepastian hukum. Penyelesaian sengketa tanah dapat ditempuh melalui cara berikut ini :

\section{Musyawarah (Negotiation)}

Musyawarah atau negosiasi salah satu penyelesaian sengketa digunakan oleh 
Basyirah Mustarin

berbagai pihak dalam menyelesaikan sengketa pertanahan. Dalam UU Nomor 30 Tahun 1999 tentang Arbitrase dan Alternatif Penyelesaian Sengketa cara musyawarah atau negoisasi disebutkan dalam pasal 6 ayat (2).

Musyawarah atau negoisasi berasal dari bahasa Inggris, negotiation yang artinya perundingan. Dalam istilah sehari-hari negoisasi sepadan dengan istilah berunding, bermusyawarah atau bermufakat. Penyelesaian secara musyawarah juga dikenal dengan sebutan penyelesaian secara bipartit yaitu penyelesaian yang dilakukan oleh para pihak yang sedang berselisih. Orang yang mengadakan perundingan disebut negosiator.

Dengan demikian musyawarah atau negosiasi merupakan bentuk penyelesaian sengketa diluar pengadilan atau non litigasi yang dilakukan sendiri oleh pihak yang bersengketa atau oleh kuasanya, tanpa bantuan dari pihak lain, dengan cara musyawarah atau berunding untuk mencari pemecahan yang dianggap adil di antara para pihak. Hasil dari musyawarah atau negosiasi berupa penyelesaian kompromi (compromise solution) yang tidak mengikat secara hukum.

Jika musyawarah berhasil dilakukan dan mencapai kesepakatan, maka akan dibuatkan perjanjian bersama yang isinya mengikat para pihak. Sebaliknya, jika dalam waktu 14 hari tidak mencapai kesepakatan maka atas kesepakatan tertulis kedua belah pihak, sengketa diselesaikan melalui konsiliasi ataupun mediasi. Penyelesaian sengketa dengan cara musyawarah atau negosiasi memungkinkan dilakukan untuk sengketa tanah dengan objek tanah belum terdaftar.

\section{Konsiliasi}

Konsiliasi adalah penyelesaian konflik, termasuk konflik pertanahan yang ditengahi oleh seorang atau lebih konsiliator yang netral yang dipilih atas kesepakatan para pihak. Konsiliator tersebut harus terdaftar di kantor yang berwenang menangani masalah pertanahan, dalam hal ini Kantor Pertanahan itu sendiri. Konsiliator harus dapat menyelesaiakan perselisihan tersebut paling lama 30 hari sejak menerima permintaan penyelesaian konflik tersebut. Pada kesempatan pertama tersebut, konsiliator wajib mendamaikan para pihak terlebih dahulu. Jika terjadi kesepakatan damai, maka dibuatkan perjanjian bersama untuk kemudian didaftarkan di pengadilan wilayah hukum mana kesepakatan itu dibuat. 
Bila konsiliator gagal mendamaikan para pihak, konsiliator mengeluarkan anjuran penyelesaian tertulis paling lambat 10 hari kerja sejak sidang konsiliasi pertama. Persetujuan atau penolakan para pihak yang berkonflik tersebut harus disampaikan oleh para pihak yang berkonflik paling lama 10 hari kerja sejak menerima anjuran tertulis dari konsiliator.

Apabila para pihak menyetujui anjuran tertulis dari konsiliator, maka dibuatkan lagi perjanjian bersama untuk didaftarkan di pengadilan wilayah mana tanah yang menjadi objek konflik untuk mendapatkan akta bukti pendaftaran, bahwa konflik diantara para pihak telah diselesaikan secara konsiliasi. Tetapi bila anjuran tertulis tersebut ditolak oleh salah satu pihak atau kedua belah pihak, maka salah satu pihak atau kedua belah pihak dapat mengajukan penyelesaian ke pengadilan setempat dengan mengajukan gugatan. Penyelasain sengketa dengan cara konsiliasi tidak cocok digunakan untuk sengketa tanah dengan objek tanah belum terdaftar.

\section{Arbitrase}

Penyelesaian sengketa dengan cara ini merupakan pengendalian konflik atau sengketa yang dilakukan dengan cara kedua belah pihak yang bertentangan bersepakat untuk menerima atau terpaksa akan hadirnya pihak ketiga yang akan memberikan keputusan bagi mereka dalam menyelesaikan konflik tersebut. Dalam penyelesaian secara arbitrase, kedua belah pihak sepakat untuk mendapatkan keputusan yang bersifat legal sebagai jalan keluar bagi konflik yang terjadi di antara para pihak. Dalam metode ini, seorang arbitrator atau majelis arbitrator adalah orang yang berperan untuk menyelesaikan konflik tersebut.

Secara umum proses persidangan arbitrase dapat melalui beberapa tahap. Mulai dari upaya damai, jawaban termohon, tanggapan pemohon, pemeriksaan bukti, keterangan saksi dam ahli, kesimpulan akhir para pihak, dan terakhir pembacaan putusan. Putusan arbitrase bersifat final, mempunyai kekuatan hukum tetap serta mengikat para pihak. Dengan demikian terhadap putusan arbitrase tidak dapat diajukan banding, kasasi, ataupun peninjauan kembali. Metode ini mungkin untuk diterapkan dalam penyelesaian sengketa tanah belum terdaftar tetapi rumit sehingga tidak direkomendasikan oleh Kantor Pertanahan Kabupaten Grobogan. 
Basyirah Mustarin

\section{Mediasi}

Secara formal mediasi merupakan pengendalian sengketa dan konflik pertanahan yang dilakukan dengan cara membuat konsensus di antara dua pihak yang berkonflik untuk mencari pihak ketiga yang berkedudukan netral sebagai mediator dalam penyelesaian sengketa dan konflik pertanahan. Penyelesaian sengketa pertanahan melalui cara mediasi, kedua belah pihak sepakat mencari nasehat dari pihak ketiga. Mediasi dilakukan atas dasar kesepakatan kedua pihak yang bersengketa bahwa masalah mereka akan diselesaikan melalui bantuan seorang atau beberapa penasehat ahli maupun seorang mediator. Pihak ketiga yang memberikan bantuan ini harus bersifat netral (tidak memihak) serta independen, dalam artian tidak dapat diintervensi oleh salah satu pihak. Penyelesaian sengketa tanah belum terdaftar dengan cara mediasi adalah alternatif pilihan penyelesaian sengketa non litigasi yang paling tepat untuk digunakan oleh mediator, dalam hal ini yang berlaku sebagai mediator adalah pihak Kantor Pertanahan itu sendiri. ${ }^{4}$

\section{Wujud Penyelesaian Sengketa Tanah}

Pada hakikatnya, kasus pertanahan merupakan benturan kepentingan (conflict of interest) di bidang pertanahan antara siapa dengan siapa, sebagai contoh konkret antara perorangan dengan perorangan; perorangan dengan badan hukum; badan hukum dengan badan hukum dan lain sebagainya.Sehubungan dengan hal tersebut di atas, guna kepastian hukum yang diamanatkan UUPA, maka terhadap kasus pertanahan dimaksud antara lain dapat diberikan respons/reaksi/penyelesaian kepada yang berkepentingan (masyarakat dan pemerintah). Wujud penyelesaian sengketa tanah terbagi atas dua yaitu:

\section{Perdamaian}

Perdamaian adalah suatu persetujuan dimana kedua belah pihak dengan menyerahkan, menjanjikan atau menahan suatu barang, mengakhiri suatu sengketa yang sedang bergantung atau mencegah timbulnya suatu perkara, dan persetujuan perdamaian tidak sah melainkan harus dibuat secara tertulis.

\footnotetext{
${ }^{4}$ Limbong, Bernhard, Konflik Pertanahan (Jakarta : Margaretha Pustaka. 2012), h. 335.
} 
2. Keputusan

Keputusan adalah penarikan kesimpulan keterangan dari semua pihak yang bersengketa, sehingga adanya atau timbulnya putusan yang kemudian hasil keputusan ini disampaikan kepala desa selaku mediator sekaligus hakim dalam permasalahan yang terjadi kepada para pihak yang bersengketa.

\section{PENUTUP}

Sertifikat merupakan surat tanda bukti hak yang berlaku sebagai alat pembuktian yang kuat mengenai data fisik dan data yuridis yang termuat di dalamnya, sepanjang data fisik dan data yuridis tersebut sesuai dengan data yang ada dalam surat ukur buku tanah yang bersangkutan. Dalam hal atas suatu bidang tanah sudah diterbitkan sertifikat secara sah atas nama orang atau badan hukum yang memperoleh tanah tersebut dengan itikad baik dan secara nyata menguasainya, maka pihak lain yang merasa mempunyai hak atas tanah itu tidak dapat lagi menuntut pelaksanaan hak tersebut apabila dalam kurung waktu 5 tahun sejak diterbitkanya sertifikat itu tidak mengajukan keberatan secara tertulis kepada pemegang sertifikat dan kepala Kantor Pertanahan yang bersangkutan ataupun tidak mengajukan gugatan ke pengadilan mengenai penguasaan tanah atau penerbitan sertifikat. Hal ini berarti bahwa data fisik dan data yuridis yang tercantum dalam sertifikat mempunyai kekuatan hukum dan harus diterima oleh hakim sebagai keterangan yang benar selama dan sepanjang tidak ada alat bukti lain yang membuktikan sebaliknya. Dengan demikian, pengadilanlah yang berwenang memutuskan alat bukti mana yang benar dan apabila terbukti sertifikat tersebut tidak benar, maka diadakan perubahan pembetulan sebagaimana mestinya. Ketentuan dalam Pasal 5 UUPA memberikan tempat dan pengakuan terhadap hak-hak masyarakat hukum adat yang terkait dengan kepemilikan atas tanah yang belum terdaftarkan ataupun belum memiliki sertifikat sepanjang tidak bertentangan dengan undang-undang nasional. Hukum adat dijadikan sebagai dasar hukum agraria nasional (yang baru), adalah merupakan suatu penegasan pengakuan terhadap hukum yang dominan dan telah disempurnakan sesuai dengan kepentingan masayarakat dan negara modern dan dalam hubungannya dengan dunia internasional. 


\section{DAFTAR PUSTAKA}

Sutedi, Adrian. Peralihan Hak Atas Tanah Dan Pendaftarannya. Sinar Grafika, Jakarta, 2007.

Harsono, Boedi. Hukum Agraria Indonesia. Jakarta : PT. Penerbit Djambatan, 2007.

Suparman, Eman. Hukum Waris Indonesia. PT Refika Aditama, Bandung, 2011.

Hartanto Andy J. Hukum Pertanahan Karakteristik Jual Beli Tanah Yang Belum

Terdaftar Hak Atas Tanahnya, Laksbang justitia Surabaya, Surabaya, 2014.

Ni'matul, Huda. Hukum Pemerintahan Daerah, Nusamedia, Bandung, 2010.

Hutagalung, Sukanti, Arie, dan Gunawan, Markus, Kewenangan Pemerintah di Bidang Pertanahan, Radjawali Press, Jakarta, 2008.

Bernhard, Limbong. Konflik Pertanahan. Margaretha Pustaka. Jakarta. 2012

Suriansyah, Murhaini. Hukum Pemerintahan Daerah (Kewenangan Pemerintah Daerah Mengurus Bidang Pertanahan), Penerbit LaksBang Grafika. Cet. II;, Perwakilan Jawa Timur dan Indonesia Timur, 2016.

Josef, Monterio Mario. Hukum Pemerintahan Daerah, Penerbit Pustaka Yustisia, Cet. I; Yogyakarta, 2016

Nurcholis, Hanif. Teori dan Praktik Pemerintahan dan Otonomi daerah. Jakarta:

Grasindo. 2005

Pemerintah Pertahankan Keberadaan Kantor Badan Pertanahan Nasional di Daerah, Harian Jawapos, Surabaya, 19 Juni 2003.

Usman, Rachmadi. Pilihan Penyelesaian Sengketa Di Luar Pengadilan. 2003.

Purwo, Santoso. Pembaharuan Desa Secara Partisipatif. Pustaka Pelajar,Yogyakarta, 2003.

Supriadi. HukumAgraria. Sinar Grafika. Jakarta, 2007

Bayu, Surianingrat. Desa dan Kelurahan Menurut UU No. 5 Tahun 1979. Metro Pos, Jakarta, 1980.

Rahmadi, Takdir. Mediasi: Penyelesaian Sengketa Melalui Pendekatan Mufakat. Jakarta: PT Rajagrafindo Persada, 2010. 